\title{
A novel mechanism of hippocampal LTD involving muscarinic receptor-triggered interactions between AMPARs, GRIP and liprin- $\alpha$
}

\author{
Bryony A Dickinson ${ }^{1}$, Jihoon Jo1,2, Heon Seok¹, Gi Hoon Son ${ }^{1}$, \\ Daniel J Whitcomb ${ }^{1,2}$, Ceri H Davies ${ }^{3}$, Morgan Sheng ${ }^{4}$, \\ Graham L Collingridge ${ }^{2}$ and Kwangwook Cho*1,2
}

\begin{abstract}
Address: ${ }^{1}$ Henry Wellcome Laboratories for Integrative Neuroscience and Endocrinology (LINE), Faculty of Medicine and Dentistry, University of Bristol, Whitson Street, Bristol BS1 3NY, UK, ${ }^{2}$ Department of Anatomy, University of Bristol, MRC Centre for Synaptic Plasticity, University Walk, Bristol BS8 1TD, UK, ${ }^{3}$ Neurosciences CEDD, GlaxoSmithKline, New Frontiers Science Park North, Third Avenue, Harlow, Essex CM19 5AW, UK and ${ }^{4}$ Department of Brain and Cognitive Sciences, Picower Institute for Learning and Memory, Massachusetts Institute of Technology, Cambridge, Massachusetts 02139, USA

Email: Bryony A Dickinson - b.dickinson@bristol.ac.uk; Jihoon Jo - Jihoon.Jo@bristol.ac.uk; Heon Seok - Heon.Seok@bristol.ac.uk; Gi Hoon Son - nsghs@bristol.ac.uk; Daniel JWhitcomb - d.whitcomb.06@bristol.ac.uk; Ceri H Davies - Ceri.2.Davies@gsk.com; Morgan Sheng - msheng@mit.edu; Graham L Collingridge - g.l.collingridge@bristol.ac.uk; Kwangwook Cho* - Kei.Cho@bristol.ac.uk

* Corresponding author
\end{abstract}

Published: 17 June 2009

Molecular Brain 2009, 2:18 doi:10.1186/1756-6606-2-18

This article is available from: http://www.molecularbrain.com/content/2/1/18

(c) 2009 Dickinson et al; licensee BioMed Central Ltd.

This is an Open Access article distributed under the terms of the Creative Commons Attribution License (http://creativecommons.org/licenses/by/2.0), which permits unrestricted use, distribution, and reproduction in any medium, provided the original work is properly cited.

\begin{abstract}
Background: Long-term depression (LTD) in the hippocampus can be induced by activation of different types of G-protein coupled receptors, in particular metabotropic glutamate receptors ( $m G l u R s)$ and muscarinic acethycholine receptors (mAChRs). Since mGluRs and mAChRs activate the same G-proteins and isoforms of phospholipase C (PLC), it would be expected that these two forms of LTD utilise the same molecular mechanisms. However, we find a distinct mechanism of LTD involving GRIP and liprin- $\alpha$.
\end{abstract}

Results: Whilst both forms of LTD require activation of tyrosine phosphatases and involve internalisation of AMPARs, they use different molecular interactions. Specifically, mAChR-LTD, but not mGluR-LTD, is blocked by peptides that inhibit the binding of GRIP to the AMPA receptor subunit GluA2 and the binding of GRIP to liprin- $\alpha$. Thus, different receptors that utilise the same G-proteins can regulate AMPAR trafficking and synaptic efficacy via distinct molecular mechanisms.

Conclusion: Our results suggest that mAChR-LTD selectively involves interactions between GRIP and liprin- $\alpha$. These data indicate a novel mechanism of synaptic plasticity in which activation of MI receptors results in AMPAR endocytosis, via a mechanism involving interactions between GluA2, GRIP and liprin- $\alpha$.

\section{Background}

Cholinergic neurotransmission in the brain has a critical role in cognition [1-4]. In particular, inhibition of mus- carinic receptors produces pronounced amnesia and loss of cholinergic innervation is an early feature of Alzheimer's disease $(\mathrm{AD})[5-8]$. As a result, the primary treat- 
ment for the cognitive deficits in $\mathrm{AD}$ is cholinesterase inhibitors, used to increase the amount of ACh available to activate neurons. In addition, there is increasing interest in the use of agents that specifically activate muscarinic AChRs (mAChRs) for the treatment of both AD [9-11] and schizophrenia [12]. It is therefore extremely important to understand how ACh regulates synaptic function, particularly that which is relevant to learning and memory.

In this context, activation of mAChRs using carbachol (CCh) induces LTD of excitatory synaptic transmission in various brain regions, including the visual cortex [13-15], perirhinal cortex $[16,17]$ and hippocampus $[13,18-21]$. However, the molecular mechanisms of mAChR-dependent LTD are poorly understood. In the present study we have therefore investigated the mechanisms involved in CCh-induced LTD (mAChR-LTD) in the hippocampus of adult rats. We find that activation of $\mathrm{M} 1$ receptors results in an LTD that is dependent on the activity of protein tyrosine phosphatases (PTPs), but is independent of $\mathrm{Ca}^{2+}$, $\mathrm{PKC}$, serine/threonine protein phosphatases and protein synthesis. In all of these respects, this form of LTD is the same as that induced by activation of mGlu 5 receptors in hippocampal slices obtained from adult animals [22,23]. However, to our surprise, we found that mAChR-LTD, but not mGluR-LTD, involves interactions between GRIP and the AMPAR subunit GluA2 (IUPHAR nomenclature for subunits previously known as GluR2 or GluRB; see [24]). Furthermore, mAChR-LTD also selectively involves interactions between GRIP and liprin- $\alpha$. These data indicate a novel mechanism of synaptic plasticity in which activation of M1 receptors results in AMPAR endocytosis, via a mechanism involving interactions between GluA2, GRIP and liprin- $\alpha$.

\section{Results \\ Carbachol induces an NMDAR-independent form of LTD in the CAI area}

Bath application of carbachol (CCh; $50 \mu \mathrm{M}, 10 \mathrm{~min}$ ) resulted in LTD of synaptic transmission in the CA1 region of the hippocampus in $4-5$ week old rats $(56 \% \pm$ $7 \%$ of baseline, quantified 30 min following washout of $\mathrm{CCh} ; \mathrm{n}=8$ ) (Figure $1 \mathrm{~A}$ ). A similar LTD was induced when CCh was applied in the presence of an NMDAR antagonist, D-AP5 $(58 \% \pm 5 \%, n=9)$ (Figure $1 B)$, demonstrating that this is an NMDAR-independent form of synaptic plasticity. The AChR-LTD involved activation of $\mathrm{M} 1$ receptors, since it was significantly reduced by pirenzepine $(0.5 \mu \mathrm{M})$ $(88 \% \pm 7 \%, n=5[p<0.05$ vs control LTD]) (Figure 1C). In addition, the $\mathrm{M} 1$ selective agonist 77-LH-28-1 $(10 \mu \mathrm{M})$ induced a slow-onset LTD $(60 \% \pm 8 \%, \mathrm{n}=6)$ (Figure 1D) that was also resistant to treatment with D-AP5 (61\% \pm $7 \%, \mathrm{n}=5$ ) (Figure $1 \mathrm{E}$ ) and was blocked by pirenzepine $(93 \% \pm 11 \%, \mathrm{n}=7$ [p $<0.05$ vs control] $)$ (Figure 1F). The
CCh-induced LTD resembles that induced by group I mGluRs and so could conceivably be due to CCh facilitation of endogenous L-glutamate actions on group I mGluRs. However, this was not the case, since CChinduced LTD was completely resistant to inhibitors of group I mGluRs ( $58 \% \pm 13 \%, \mathrm{n}=6)$ (Figure 1G).

To investigate the expression mechanism of this mAChRLTD, we performed surface biotinylation assays using hippocampal slices. Hippocampal slices were treated with $\mathrm{CCh}$, in the presence or absence of pirenzepine, and the cell surface and total expression level of GluA2 subunits was compared. CCh induced a substantial internalisation of GluA2 subunits (Figure $1 \mathrm{H}$ ), consistent with a mechanism that involves the internalisation of AMPARs [20].

\section{Signalling mechanisms involved in mAChR-LTD}

$\mathrm{M} 1$ receptors conventionally signal via $\mathrm{IP}_{3}$-induced $\mathrm{Ca}^{2+}$ release from intracellular stores and/or activation of PKC [25-28]. However, intracellular infusion of cyclopiazonic acid (CPA, $2 \mu \mathrm{M})$, which depletes $\mathrm{Ca}^{2+}$ stores, had no effect on mAChR-LTD $(52 \% \pm 6 \%, \mathrm{n}=6)$ (Figure $2 \mathrm{~A})$. Similarly, postsynaptic infusion of either the PKC inhibitor Ro 32-0432 $(10 \mu \mathrm{M}, 53 \% \pm 7 \%, \mathrm{n}=6)$ (Figure $2 \mathrm{~B})$ or the inhibitory peptide $\mathrm{PKC}_{19-31}(10 \mu \mathrm{M} ; 64 \% \pm 7 \%, \mathrm{n}=9)$ (data not shown) had no effect on mAChR-LTD. Therefore, it would seem that mAChR-LTD involves an unconventional signalling mechanism. An alternative possibility is that mAChR-LTD involves a different $\mathrm{Ca}^{2+}$ dependent process, since most forms of synaptic plasticity are $\mathrm{Ca}^{2+}$-dependent [29]. However, postsynaptic infusion of BAPTA $(10 \mathrm{mM})$ had no effect on mAChR-LTD $(61 \% \pm$ $9 \%, \mathrm{n}=9$ ) (data not shown).

The serine/threonine protein phosphatases PP1 and PP2B (calcineurin) are required for NMDAR-dependent LTD $[30,31]$. To determine whether these enzymes are important for mAChR-LTD we included either okadaic acid or cyclosporin-A in the whole-cell solution. However, neither okadaic acid ( $100 \mathrm{nM}, 66 \% \pm 8 \%, \mathrm{n}=5$ ) (Figure $2 \mathrm{C}$ ) nor cyclosporin-A $(10 \mu \mathrm{M}, 64 \% \pm 7 \%, \mathrm{n}=7)$ (data not shown) had any effect on mAChR-LTD. Another candidate mechanism for mAChR-LTD involves protein synthesis $[16,20]$. Therefore it was surprising to find that neither of the protein translation inhibitors anisomycin $(20 \mu \mathrm{M}$, $68 \% \pm 7 \%, \mathrm{n}=7)$ (Figure 2D) nor cycloheximide $(80 \mu \mathrm{M}$, $70 \% \pm 8 \%, \mathrm{n}=7$ ) (data not shown) had any significant effect on mAChR-LTD.

These negative findings are reminiscent of mGluR-LTD in the CA1 region of the hippocampus of adult rats $[22,23]$. Since this latter form of LTD is blocked by broad spectrum PTP inhibitors, we tested orthovanadate and phenylarsine oxide (PAO) on mAChR-LTD. Both orthovanadate (100 $\mu \mathrm{M}, 101 \% \pm 5 \%, \mathrm{n}=5)$ (Figure $2 \mathrm{E})$ and PAO $(1.5 \mu \mathrm{M}$, 
A

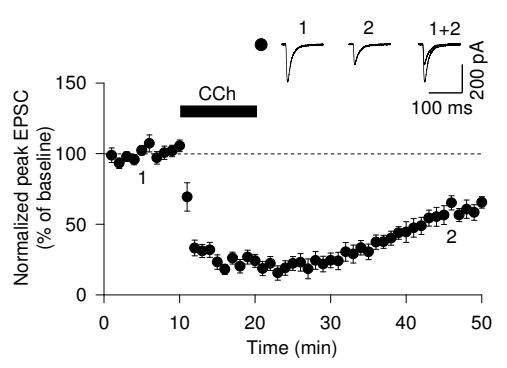

B

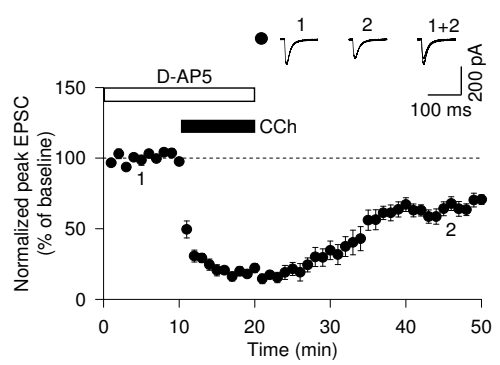

C
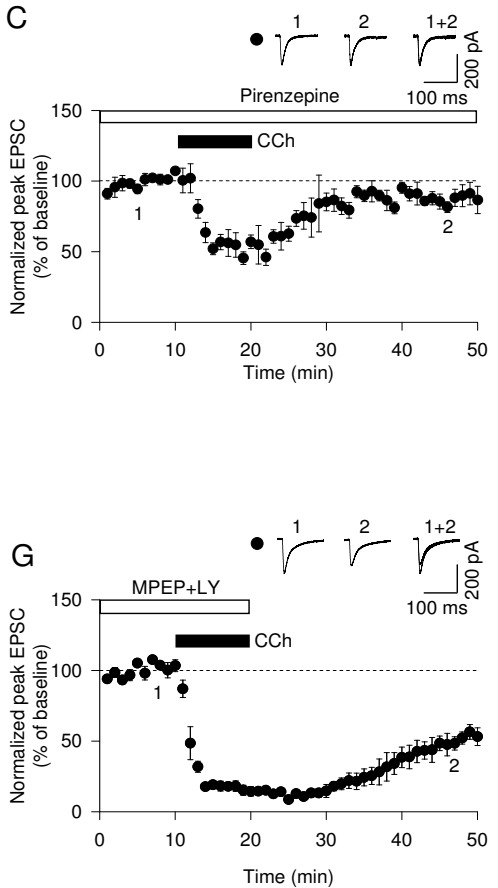

D

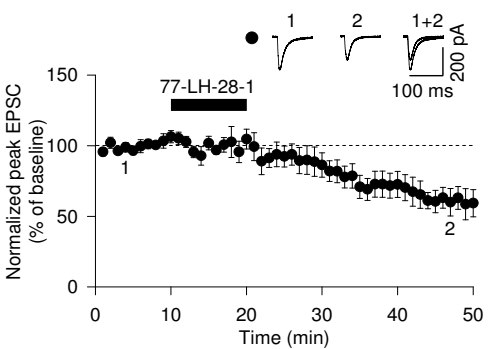

E

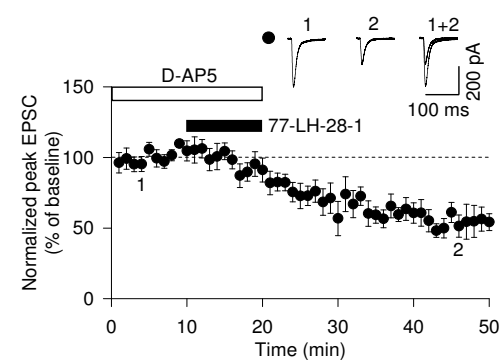

$\mathrm{F}$

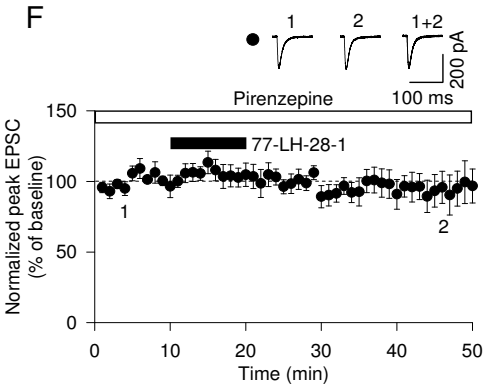

$\mathrm{H}$

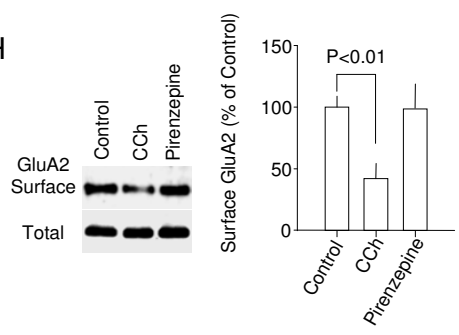

Figure I

Properties of CCh-induced LTD in the CAI region of the hippocampus. (A) A pooled data $(n=8)$ of EPSC amplitude vs time to show that carbachol application (CCh, $50 \mu \mathrm{M}, 10 \mathrm{~min}$ ) induces mAChR-LTD. (B) D-AP5 (50 $\mu$ M) has no effect on mAChR-LTD $(n=9)$. (C) mAChR-LTD was prevented by bath application of an MI mAChR antagonist, pirenzepine $(0.5 \mu M, n$ = 5). (D) The MI specific agonist, 77-LH-28-I, induces LTD $(n=6)$. (E) D-AP5 $(50 \mu M)$ has no effect on LTD induced by 77 LH-28-I $(n=5)$. (F) Pirenzepine $(0.5 \mu M)$ prevents LTD induced by 77-LH-28-I $(n=7)$. (G) Co-application of LY367385 (I00 $\mu \mathrm{M})$ and MPEP $(50 \mu \mathrm{M})$ has no effect on mAChR-LTD $(n=6) .(\mathrm{H})$ An example of biotinylation from hippocampal slices. Pooled data $(n=4)$ shows that $C C h$ induces internalisation of GluA2. Error bars represent s.e.m. 
A

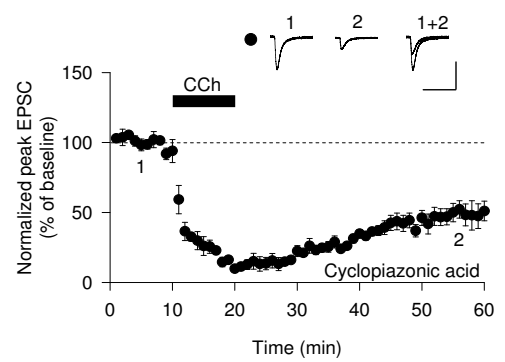

C

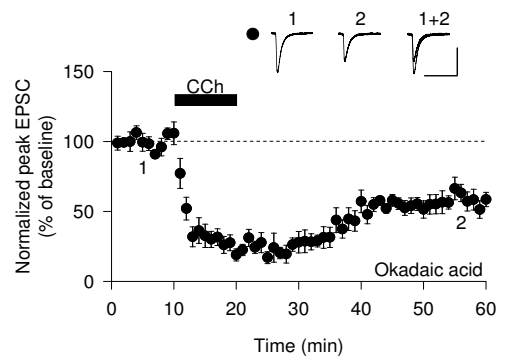

E

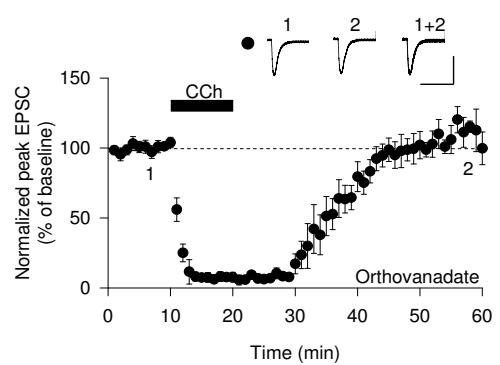

G

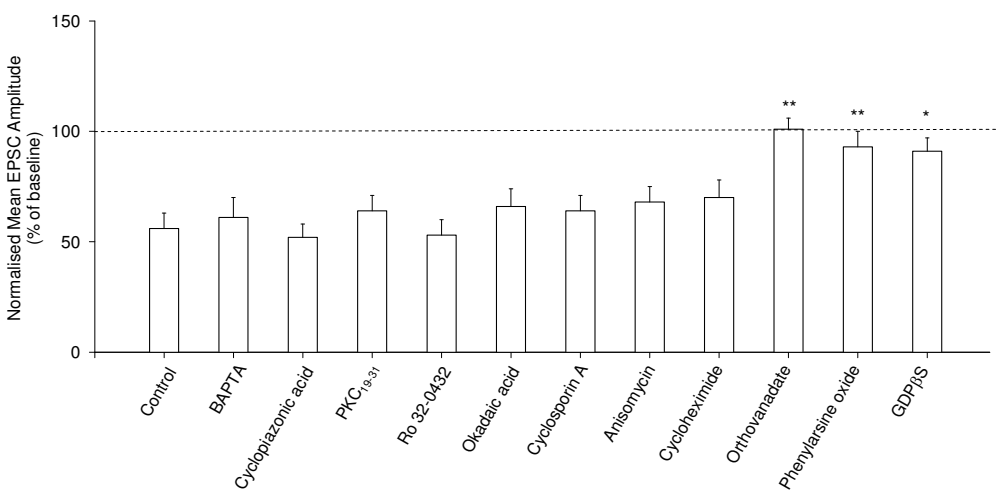

B

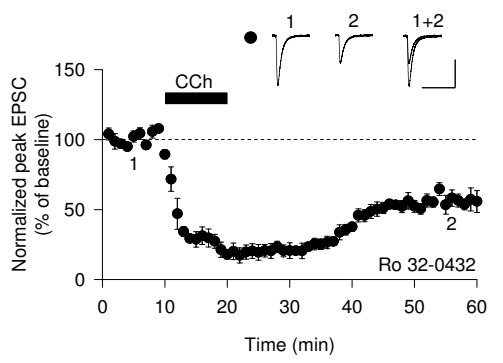

D

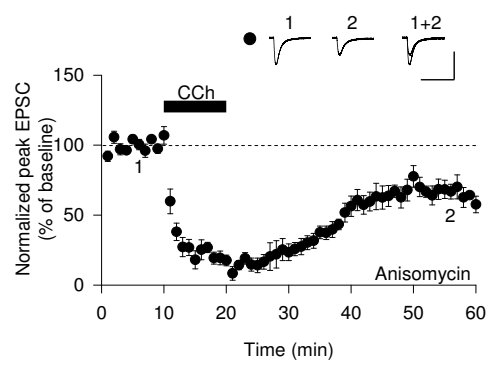

F

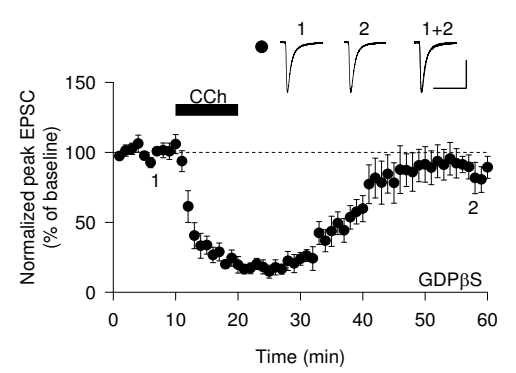

\section{Figure 2}

Signalling mechanisms involved in mAChR-LTD. (A) Cyclopiazonic acid $(2 \mu M)$ has no effect on mAChR-LTD $(n=6)$. (B) Ro 32-0432 (I0 $\mu M)$ has no effect on mAChR-LTD $(n=6)$. (C) Okadaic acid $(100 \mathrm{nM})$ has no effect on $m A C h R-L T D(n=$ 5). (D) Anisomycin $(20 \mu M)$ has no effect on mAChR-LTD $(n=7)$. (E) Orthovanadate $(100 \mu M)$ prevents the induction of mAChR-LTD $(n=5)$. (F) GDPßS (I mM) blocks the induction of mAChR-LTD $(n=6)$. $(G)$ A summary of results from control $(n=8)$, BAPTA $(n=9)$, cyclopiazonic acid $(n=6)$, PKCI9-3I $(n=9)$, Ro 32-0432 $(n=6)$, okadaic acid $(n=5)$, cyclosporin A $(n=7)$, anisomycin $(n=7)$, cycloheximide $(n=7)$, orthovanadate $(n=5)$, phenylarsine oxide $(n=7)$ and GDP SS $(n=6)$, experiments. $* \mathrm{P}<0.05$ vs control $* * \mathrm{P}<0.0$ l vs control. 
$93 \% \pm 7 \%, \mathrm{n}=7$ ) (data not shown) blocked mAChR-LTD. Finally, we tested whether, like mGluR-LTD [32], mAChRLTD requires activation of G-proteins or whether it operates in a G-protein independent manner (see [33]). Postsynaptic inclusion of guanosine-5'-O-(2thiodiphosphate) (GDP $\beta S$ ) inhibited mAChR-LTD (1 $\mathrm{mM}, 91 \% \pm 6 \%, \mathrm{n}=6$ ) (Figure $2 \mathrm{~F}$ ), confirming that a Gprotein signalling mechanism is involved. These results, which are summarised in Figure 2G, show that mAChRLTD involves very similar signalling mechanisms to that previously described for mGluR-LTD in adult hippocampus $[22,23,32]$.

\section{An interaction between GluA2 and GRIP is necessary for mAChR-LTD}

How activation of PTPs results in LTD is not known, but the finding that both mGluR-LTD and mAChR-LTD involve internalisation of AMPARs suggests that proteins that interact with these receptors might be involved. In the ventral tegmental area (VTA) it has been shown that blocking the interaction between GluA2 and PICK1, with the peptide inhibitor pep2-EVKI (YNVYGIEEVKI) [34,35], prevents mGluR-LTD [36]. In addition, blocking GluA2 interactions with PICK1 also prevents mGluR-LTD in the cerebellum [37]. We therefore included pep2-EVKI (100 $\mu \mathrm{M})$ in the whole-cell solution and compared its effects with that of a control peptide, pep2-SVKE $(100 \mu \mathrm{M})$, which has no effect on GluA2-PDZ interactions [34,35]. We found that neither pep2-EVKI $(64 \% \pm 6 \%, n=9)$ (Figure $3 \mathrm{~A})$ nor pep2-SVKE $(67 \% \pm 13 \%, \mathrm{n}=6)$ (Figure $3 \mathrm{~A}$ ) had any effect on mAChR-LTD. We therefore tested pep2SVKI (YNVYGIESVKI), which in addition to blocking PICK1 interactions with GluA2 also blocks GRIP (ABP) interactions with this subunit [34,35]. We found that pep2-SVKI $(100 \mu \mathrm{M})$ caused a characteristic run-up in synaptic transmission [35] and, most surprisingly, blocked mAChR-LTD $(97 \% \pm 9 \%, n=8)$ (Figure 3B). These interfering peptide experiments suggest that GRIP rather than PICK1 is involved in mAChR-LTD.

Given the identical signalling cascades triggered by both M1 and mGlu5 receptors it was natural to assume that pep2-SVKI should also block DHPG-LTD. Remarkably, however, it did not. Thus, the levels of LTD induced in cells loaded with pep2-SVKE $(54 \% \pm 8 \%, \mathrm{n}=6)$ (Figure $3 \mathrm{C})$ and pep2-SVKI $(61 \% \pm 4 \%, \mathrm{n}=6)$ (Figure 3D) were not significantly different. These results demonstrate a divergence at the level of AMPAR trafficking between these two forms of LTD, despite the similarity in signal transduction mechanisms.

\section{GRIPI-Liprin- $\alpha$ association has a critical role in $m A C h R-$ LTD}

We sought an explanation how GRIP might be involved in mAChR-LTD. In this context, an association between
GRIP and liprin- $\alpha$ is important for synaptic targeting of AMPA receptors [38,39]. Liprin- $\alpha$ directly interacts with GRIP through its PDZ6 domain [38] and it also recruits leukocyte common antigen-related receptor (LAR) to GRIP [39]. LAR is a PTP that is known to be involved in axonal guidance and neuronal development including cholinergic network formation [40,41]. Therefore we determined whether the GRIP-liprin- $\alpha$ association has a role in mAChR-LTD.

To investigate the potential role of the GRIP-liprin- $\alpha$ association in $\mathrm{mAChR}$-LTD we included a peptide in the patch pipette (TVRTYSC) $(100 \mu \mathrm{M})$ that corresponds to the Cterminal region of liprin- $\alpha$, which is the interaction site with the PDZ6 domain of GRIP [38]. We interleaved these experiments with a control peptide (TVRTASC) $(100 \mu \mathrm{M})$, which is unable to bind to GRIP due to an alanine substitution for tyrosine in the -2 position [38]. Whilst the Cterminal fragment blocked mAChR-LTD $(98 \% \pm 9 \%, \mathrm{n}=$ 6) (Figure $4 \mathrm{~A})$ the control peptide did not $(59 \% \pm 7 \%, \mathrm{n}$ $=5$ ) (Figure 4B). To investigate whether the GRIP-liprin- $\alpha$ interaction is specifically required for mAChR-LTD we also investigated both mGluR-LTD and NMDAR-LTD. Interestingly, neither the active $(60 \% \pm 8 \%, \mathrm{n}=7)$ (Figure $4 \mathrm{C})$ nor control $(59 \% \pm 9 \%, \mathrm{n}=8)$ (Figure $4 \mathrm{D})$ peptides had any effect on DHPG-LTD. Similarly, the active $(62 \%$ $\pm 3 \%, \mathrm{n}=6)$ (Figure $4 \mathrm{E})$ and control $(62 \% \pm 6 \%, \mathrm{n}=6)$ (Figure 4F) peptides were also without effect on NMDAinduced LTD. These data indicate a specific role for the interaction between GRIP and liprin- $\alpha$ in the induction of mAChR-LTD (see Figure 5).

\section{Discussion}

In the present study we have investigated a form of LTD involving muscarinic activation that leads to tyrosine dephosphorylation and the removal of AMPARs from the cell surface. Novel aspects of this work include the observations that the process involves interactions between the GluA2 subunit and GRIP and between GRIP and liprin- $\alpha$, a protein that targets the PTP, LAR to GRIP. Remarkably, LTD induced by group I mGluRs does not utilise this same set of protein interactions, despite being triggered by activation of the same class of $G$ protein and involving similar signal transduction mechanisms. These results point to a hitherto unexpected and remarkable degree of specificity in the protein: protein interactions that are involved in very similar forms of synaptic plasticity.

\section{Receptor mechanisms involved in CCh-LTD}

LTD induced by the activation of muscarinic ACh receptors has been described in several brain regions, in particular the hippocampus [13,19-21,42], visual cortex [13$15,43]$ and perirhinal cortex $[16,17]$. In some instances the LTD is dependent on the activation of NMDARs $[13,19,43]$ whilst in others it is not $[14,16,20]$. It is estab- 
A
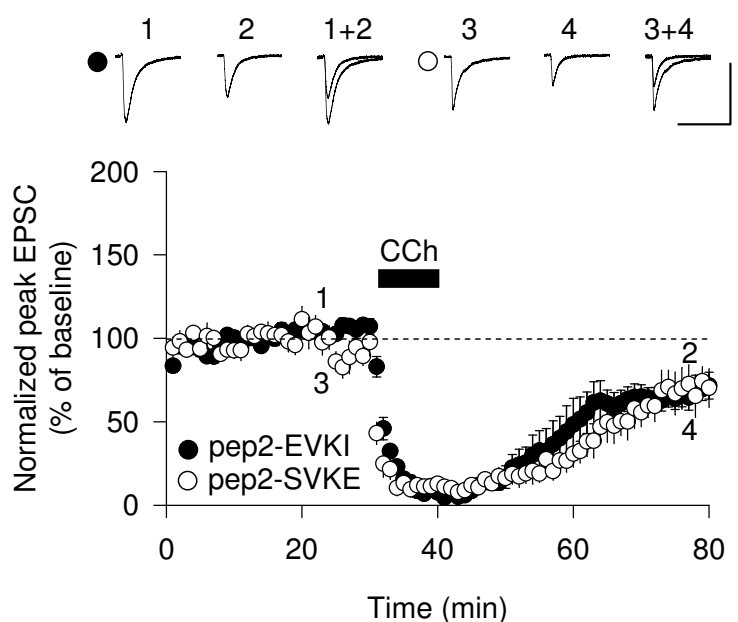

C

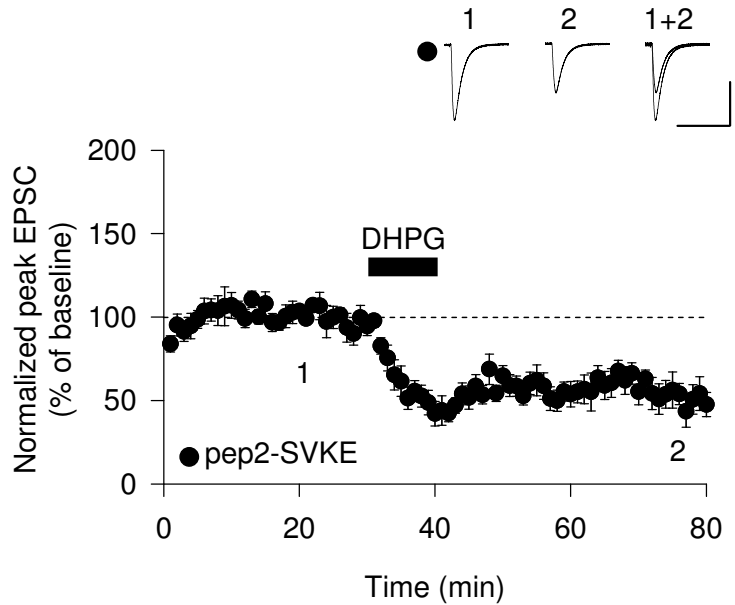

$\mathrm{B}$

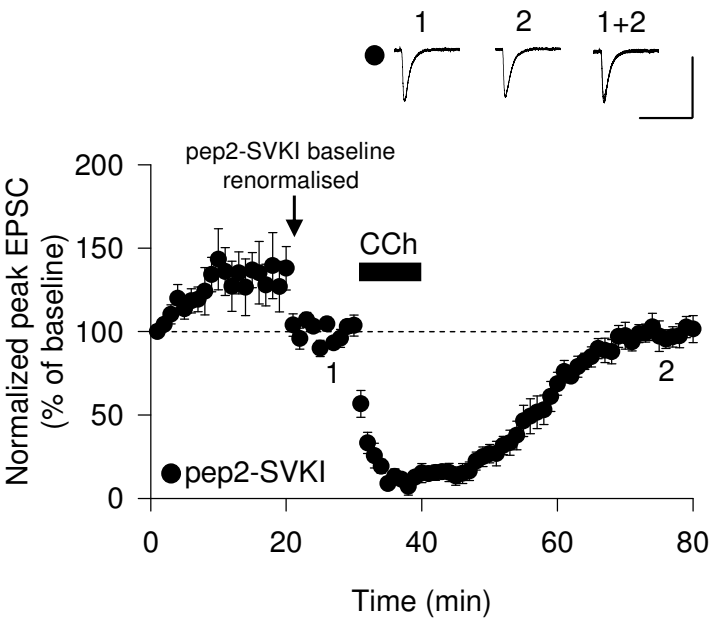

D

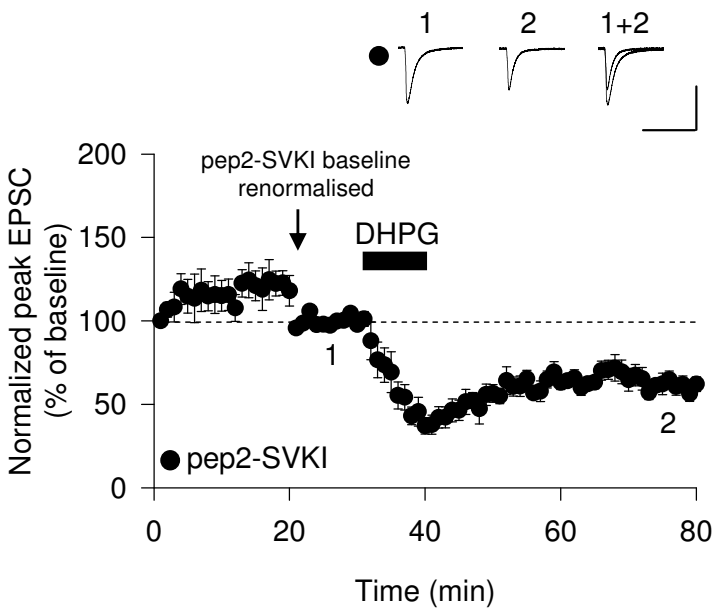

Figure 3

Interactions between GluA2 and GRIP, but not PICKI, are required for mAChR-LTD. (A) Neither pep2-SVKE (n $=6$ ) nor pep2-EVKI $(n=9)$ has any effect on mAChR-LTD. (B) Pep2-SVKI prevents mAChR-LTD $(n=8)$. (C) Pep2-SVKE $(n=$ 6) has no effect on mGluR-LTD. (D) Pep2-SVKI $(n=6)$ has no effect on mGluR-LTD.

lished that stimulation of muscarinic receptors can facilitate the activation of NMDARs [44-46]. It is likely therefore that the LTD that is sensitive to NMDAR blockade involves a muscarinic modulation of NMDARdependent LTD. In contrast, the LTD that is insensitive to NMDAR blockade is an independent form of LTD. In the present study the LTD that we have studied was of the latter variety since it was unaffected by D-AP5. This LTD resembles that induced by other Gq coupled receptors, such as the extensively characterised LTD induced through the activation of group I mGluRs by DHPG [e.g. [47-52]].
Other Gq coupled receptors can also induce LTD [21,53] suggesting that these neurotransmitters converge at the level of the G-protein with respect to their involvement in LTD. Consistent with previous work, CCh-induced LTD is mediated via activation of $\mathrm{M} 1$ receptors $[14,19]$ whilst the initial depression requires activation of a different muscarinic subtype $[19,42]$.

\section{Signalling mechanisms involved in mAChR-LTD}

We tested a number of different inhibitors of cell signalling pathways to elucidate the pathways that lead from 
A

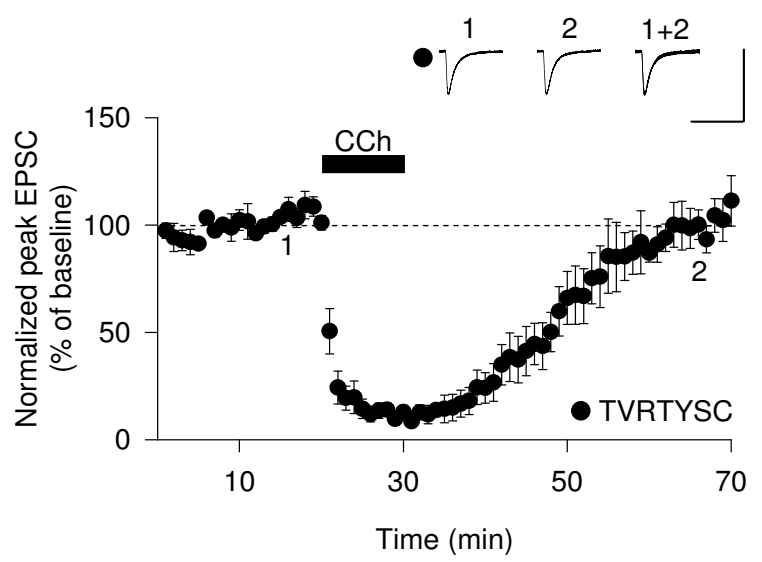

C

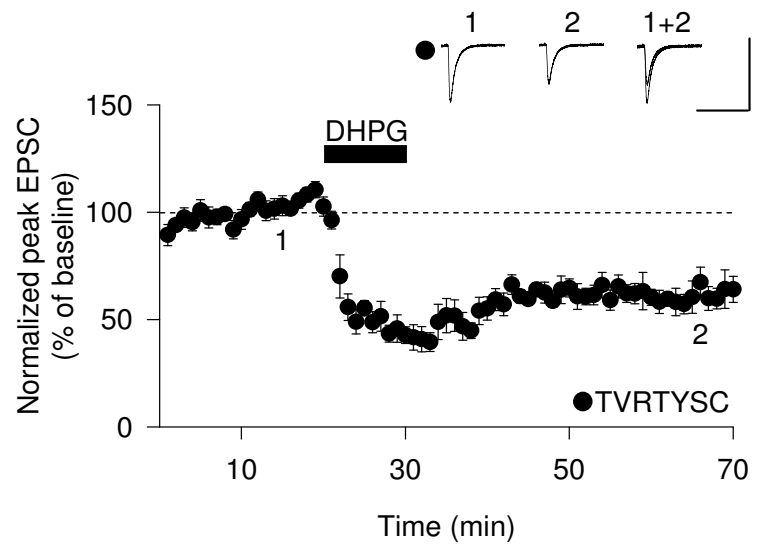

$E$

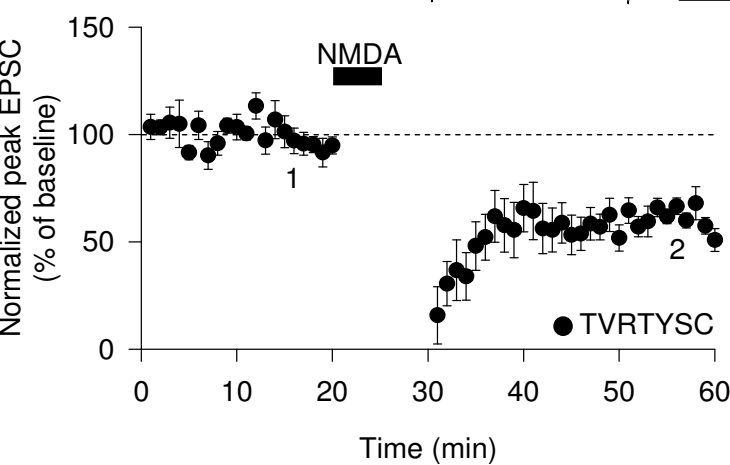

B

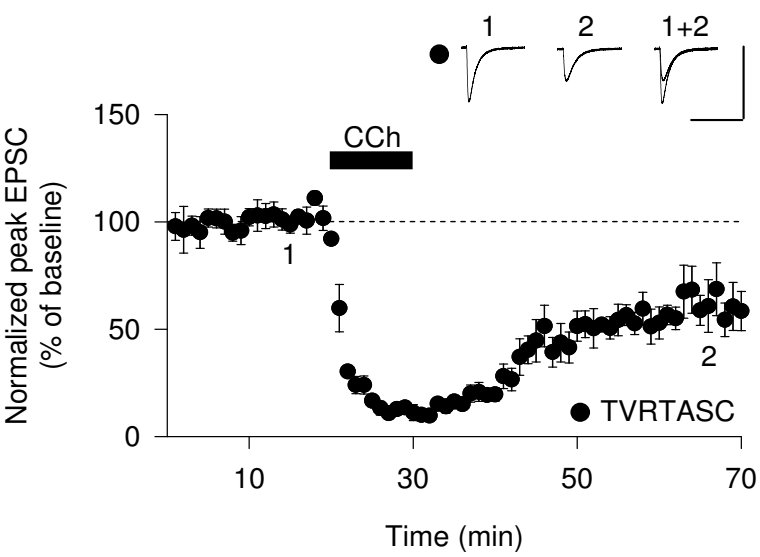

$\mathrm{D}$

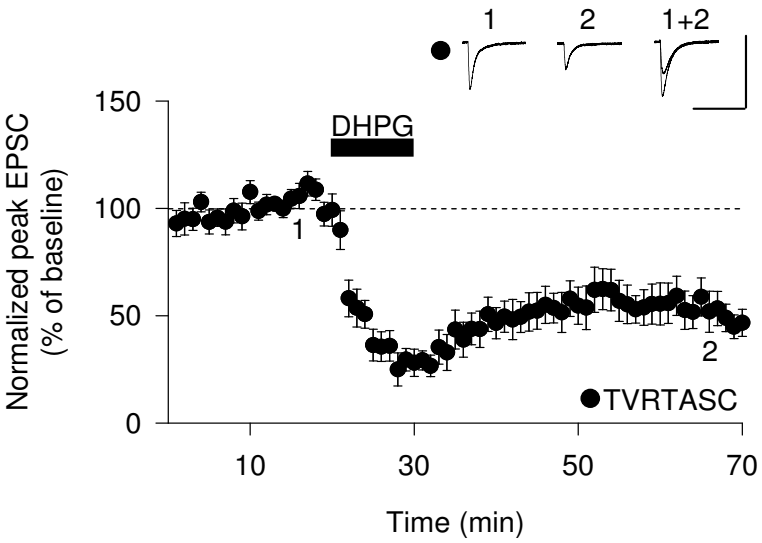

$\mathrm{F}$
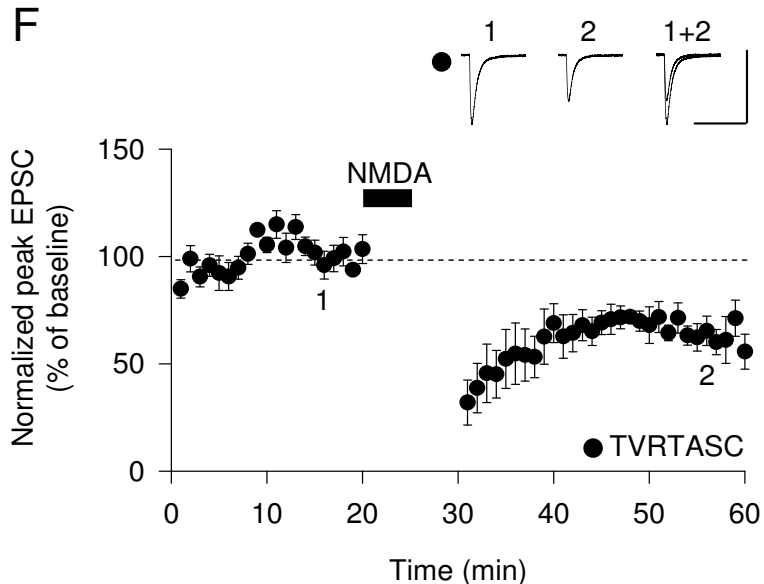

\section{Figure 4}

Interaction between liprin $\alpha$ and GRIP is required for mAChR-LTD. (A) Intracellular infusion of the $C$ terminal fragment of liprin $\alpha$ (TVRTYSC) prevents induction of mAChR-LTD $(n=6)$. (B) A control peptide (TVRTASC) has no affect on mAChR-LTD $(n=5)$. (C) TVRTYSC $(n=7)$ has no effect on mGluR-LTD. (D) TVRTASC $(n=8)$ has no effect on mGluR-LTD. (E) TVRTYSC $(n=6)$ has no effect on NMDAR-LTD. $(F)$ TVRTASC $(n=6)$ has no effect on NMDAR-LTD. 


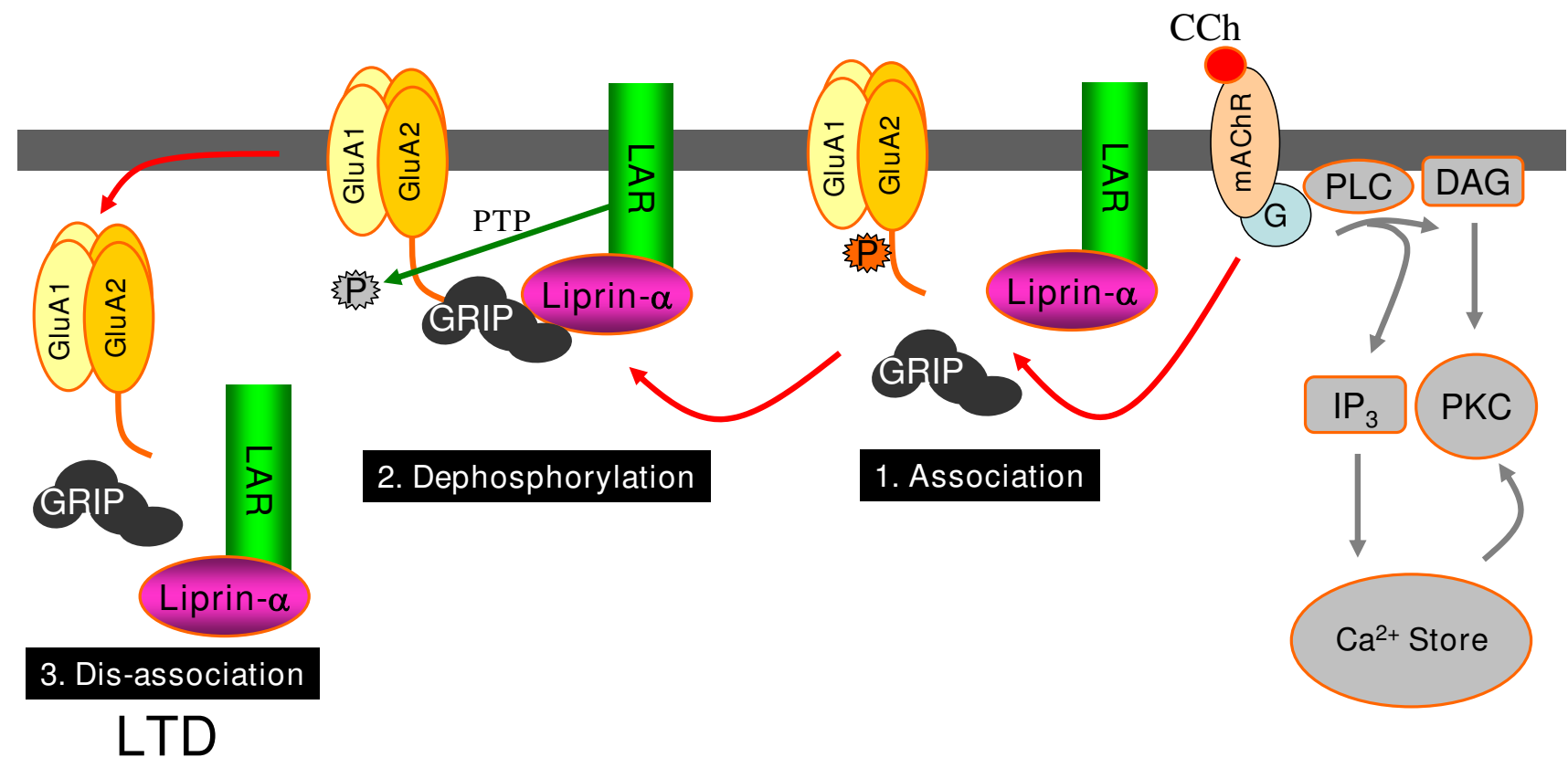

\section{Figure 5}

A novel mechanism of LTD involving liprin- $\alpha$ and LAR. Activation of mAChRs leads to a G-protein dependent mAChR-LTD that does not involve the canonical pathway (IP3 and PKC). The data can most simply be explained by GRIP acting as a targeting molecule that brings LAR and the GluA2 subunit of AMPARs into contact. This then enables LAR to dephosphorlyate a tyrosine residue (such as YGIESVKI on GluA2) which initiates the removal of the AMPAR from the synapse.

mAChR activation to AMPAR internalisation. In many cases we obtained negative results but this is not due to ineffective inhibition of the target compound. Not only were the inhibitors applied directly to the postsynaptic cell via the patch pipette, at concentrations known to be effective in other experiments, but in most cases we found, during parallel experiments, that the same compounds were effective on other forms of synaptic plasticity (e.g. [54]).

Compared to DHPG-LTD very little is known about the downstream signalling during mAChR-LTD. Classically, stimulation of $\mathrm{M} 1$ receptors leads to activation of PKC and the release of $\mathrm{Ca}^{2+}$ from intracellular stores. However, we found no evidence that either limb of this pathway was involved in mAChR-LTD. The lack of effects of PKC inhibitors agree with previous studies of LTD induced by carbachol [14] and DHPG $[55,56]$. The effect of interfering with $\mathrm{Ca}^{2+}$ stores is less clear, since a partial inhibition by CPA of CCh-LTD was observed in perirhinal cortex [16]. This might reflect a difference in brain region. In the present study, the LTD studied was also unaffected by BAPTA. This insensitivity to the chelation of intracellular $\mathrm{Ca}^{2+}$ has also been reported for DHPG-LTD [57], and suggests that the signalling pathways involved in these Gq-dependent forms of synaptic plasticity can be $\mathrm{Ca}^{2+-i n d e p e n d e n t . ~ P r e-~}$ vious work has implicated protein synthesis in mAChRLTD. In two of these studies the effect of protein translation inhibitors were apparent rapidly but were only partially effective $[16,20]$ whilst in another study these same inhibitors only affected mAChR-LTD after a delay of more than an hour [14]. In agreement with the latter report, we found no effect of protein translation inhibitors on mAChR-LTD during the duration of our experiments. A similar dichotomy has been reported with mGluR-LTD, with reports of both protein synthesis dependence [49] and independence [23], for reasons that are not clear. In terms of treatments that were effective, we did find that inhibition of PTPs completely prevented the induction of mAChR-LTD. This observation, together with the insensitivity to a serine/threonine protein phosphatase, again highlights similarities between mAChR-LTD and mGluRLTD $[22,23]$. In summary, we can conclude that activation of $\mathrm{M} 1$ receptors results in the loss of surface AMPARs and the generation of LTD via a $\mathrm{Ca}^{2+}$-independent signalling cascade that involves one or more types of PTP.

\section{A role for GRIP in $m A C h R-L T D$}

Our study has demonstrated that mAChR-LTD induced by carbachol application is dependent on the internalisation of GluA2-containing AMPA receptors (see also [20]). A number of studies have shown that the induction of vari- 
ous forms of LTD involves phosphorylation and dephosphorylation events, which regulate interactions of PDZ domain proteins with AMPA receptors and induce AMPA receptor mobilisation (see, [58]). In particular, endocytosis of GluA2-containing AMPA receptors has previously been suggested to involve the PICK1-GluA2 interaction and a dependency upon PKC phosphorylation of S880 on the GluA2 subunit [59-62]. Indeed, there is considerable evidence for a role of PICK1 in mGluR-LTD in a variety of brain regions, including the cerebellum $[37,63,64]$, VTA [65] and perirhinal cortex [54]. Surprisingly, therefore, we obtained no evidence for a role of PICK1 in mAChR-LTD in the hippocampus. This observation suggests that despite coupling to the same G-proteins and utilising similar signal transduction methods, mGluR-LTD and mAChR-LTD exploit different mechanisms at the level of AMPAR trafficking.

Whilst we found no evidence for a role of PICK1 in mAChR-LTD, we did find evidence of an essential role for GRIP. Although GRIP, and the related protein ABP, are established as important interactors with AMPARs $[35,59,66,67]$ their precise roles are not known. For example, GRIP has been implicated in the stabilisation of AMPARs at synapses $[59,61,62]$ and intracellular organelles $[35,68]$ as well as in the sorting and transport of AMPARs $[69,70]$. Our results suggest that GRIP is also involved in the regulated synaptic removal of AMPARs. Specifically, blocking the interaction of GRIP with GluA2 prevents mAChR-LTD. This suggests that GRIP targets machinery to GluA2 that is involved in their synaptic removal. Remarkably, this effect is not part of a generalised LTD mechanism triggered by Gq-coupled receptor activation since mGluR-LTD was completely unaffected by blockade of the GluA2-GRIP interaction.

\section{A role for liprin- $\alpha$ in $m A C h R-L T D$}

An important interactor of GRIP is liprin- $\alpha$ (SYD2). This molecule binds to PDZ6 of GRIP and is involved in the surface expression and synaptic clustering of AMPARs [38]. Whether liprin- $\alpha$ is involved in the acute regulation of AMPAR synaptic expression, as occurs during LTP and LTD, is unknown. Our data, showing that a peptide capable of blocking the interaction of liprin- $\alpha$ with GRIP blocks mAChR-LTD, is consistent with the possibility that liprin- $\alpha$ plays a role in the rapid removal of AMPAR from synapses. Consistent with the unique role of GRIP in mAChR-LTD we found that the peptide designed to block the interaction between GRIP and liprin- $\alpha$ selectively blocks mAChR-LTD, having no effect on two other forms of LTD.

This raises the question as to how liprin- $\alpha$ might be functioning in mAChR-LTD. It is known that liprin- $\alpha$ binds the leukocyte common antigen-related (LAR) family receptor protein tyrosine phosphatase (LAR-RPTP). These PTPs are enriched at synapses and form complexes with GRIP and AMPARs [39], making them potential phosphatases involved in synaptic plasticity. Indeed, LARRPTPs could be the target of the broad spectrum PTP inhibitors that we have shown block mAChR-LTD. In contrast, since mGluR-LTD does not involve liprin- $\alpha$, it is likely that it utilises a different PTP, such as STEP [71]. Conversely, NMDAR-LTD does not seem to involve PTPs of any kind, rather it involves serine/threonine protein phosphatases [31] and protein tyrosine kinases (PTKs) $[72,73]$. What is most clear from the present results is that there is a specific mechanism that is engaged for the regulation of synaptic AMPARs by the stimulation of muscarinic receptors, which is distinct from that employed by the activation of glutamate receptors. This might relate to the differences in the location of the glutamate receptors and muscarinic receptors that are activated by their respective neurotransmitters.

\section{Significance of the findings for cognition}

The critical involvement of ACh in cognition is well established. It is likely that the ability of muscarinic receptor activation to modulate NMDAR-dependent synaptic plasticity and to induce synaptic plasticity in an NMDARindependent manner are both important aspects of this function. Dissecting the relative roles of the cholinergic modulation of NMDAR-dependent synaptic plasticity and the cholinergic induction of LTD will be important challenges for the future. Interestingly, mGluR-LTD and mAChR-LTD are likely to be evoked under quite different conditions. The former requires strong activation of glutamatergic pathways and constitutes a form of homosynaptic plasticity. In contrast, mAChR-LTD can be induced with little or no activation of the glutamatergic system, and hence constitutes a form of heterosynaptic plasticity. In this way, cholinergic activation could simultaneously boost both NMDAR-dependent synaptic plasticity at strongly active inputs and depress transmission at inactive, or weakly active, inputs.

\section{Conclusion}

We have identified a novel mechanism of synaptic plasticity that is specifically engaged during muscarinic receptor activation. This mechanism is not utilised by mGluR activation, demonstrating that different Gq-coupled receptors can affect AMPAR trafficking via distinct molecular mechanisms.

\section{Methods \\ Electrophysiology}

Hippocampal slices were obtained from 4-5 week old male Wistar rats. Animals were sacrificed by cervical dislocation in accordance with the UK Animals Scientific Procedures Act of 1986. The brains were quickly removed and 
transferred into ice-cold artificial cerebrospinal fluid (aCSF; bubbled with $95 \% \mathrm{O}_{2} / 5 \% \mathrm{CO}_{2}$ ) containing the following: $(\mathrm{mM}) \mathrm{NaCl}, 124 ; \mathrm{KCl}, 3$; $\mathrm{NaHCO}_{3}, 26$; $\mathrm{NaH}_{2} \mathrm{PO}_{4}, 1.25 ; \mathrm{CaCl}_{2}, 2 ; \mathrm{MgSO}_{4}, 1 ; \mathrm{D}$ glucose, 10. Subsequently, a mid-sagittal cut was made in the brain and one hemisphere was placed back into the ice cold aCSF until it was required. Transverse hippocampal slices (400 $\mu \mathrm{m}$ ) were prepared using either a vibratome (Leica, Nussloch, Germany) or a McIllwain tissue chopper (Mickle Laboratory Engineering Co. Ltd., Gomshall, UK). The slices were then submerged in aCSF $\left(20^{\circ} \mathrm{C}-25^{\circ} \mathrm{C}\right)$ for at least 1 hour before recording. Slices were then transferred to the recording chamber and perfused with aCSF $\left(28^{\circ} \mathrm{C}-\right.$ $30^{\circ} \mathrm{C}$, flow rate $2 \sim 3 \mathrm{ml} / \mathrm{min}$ ). Before recording, the CA3 region of the hippocampus was severed using a scalpel cut.

Whole-cell recordings were made from pyramidal cells in the CA1 region of the hippocampus (Axopatch $200 \mathrm{~B}$ amplifier, Molecular Devices, Sunnyvale, California). The patch pipette (resistance - 4-7 M $\Omega$ ), pulled from borosilicate glass, was filled with a solution composed of $(\mathrm{mM})$ $\mathrm{CsMeSO}_{4}$, 130; NaCl, 8; Mg-ATP, 4; Na-GTP, 0.3; EGTA, 0.5; HEPES 10; QX-314, 6 (280 mOsm [pH 7.2]). CA1 pyramidal neurons were voltage clamped at $-70 \mathrm{mV}$ and AMPA receptor-mediated synaptic currents were measured in the presence of picrotoxin $(20 \mu \mathrm{M})$. Stimulating electrodes placed into the Schaffer collateral-commissural pathway, in the CA2 region, delivered stimuli at a frequency of $0.033 \mathrm{~Hz}$. Series resistance and input resistance were monitored during the experiment and experimental data was not included if changes $>10 \%$ were seen.

In all experiments a baseline of at least 10 minutes was obtained before application of CCh or 77-LH-28-1. After drug application a washout period of 30-40 minutes was obtained. In experiments where pep2-SVKI, pep2-SVKE, pep2-EVKI, TVRTYSC and TVRTASC were incorporated into the pipette filling solution (Figure 3 and 4) a 20-30 minute baseline was obtained to ensure effective loading of the peptide and for stabilization of any effects on baseline transmission. The peptides, pep2-SVKI, pep2-SVKE and pep2-EVKI were purchased from Tocris (Bristol, UK) while TVRTYSC and TVRTASC were purchased from Peptide Protein Research LTD (Fareham, Hampshire, UK). BAPTA, cyclopiazonic acid, Ro 32-0432, PKC19-31, okadaic acid, cyclosporin A, anisomycin, cycloheximide, orthovanadate, phenylarsine oxide and GDP $\beta S$ were added to the whole cell-patch filling solution. These chemicals were purchased from Calbiochem (California, U.S.A.). Picrotoxin, pirenzepine, and LY367385 were purchased from Tocris (Bristol, UK). Carbachol was purchased from SigmaAldrich (St Louis, U.S.A.). MPEP and D-AP5 was purchased from Ascent Scientific (Bristol, UK). These chemicals were made up as a stock solution and diluted to their final appropriate concentration in aCSF as required (indicated in Figures).

\section{Biotinylation}

Surface expression of GluA2 was analysed with a commercial surface labelling kit according to the manufacturer's instructions (Thermo Fisher Scientific Inc., Rockford, IL, USA). Briefly, $400 \mu \mathrm{m}$ thick hippocampal slices (6 slices for each lane) were incubated with aCSF containing $1 \mathrm{mg} /$ $\mathrm{ml}$ sulfosuccinimidyl-6-(biotinamido) hexanoate for 45 min on ice, quenched by further incubation in aCSF containing $100 \mathrm{mM}$ glycine, and followed by two washes in ice-cold Tris-buffered saline ( $50 \mathrm{mM}$ Tris, $\mathrm{pH}$ 7.5, $150 \mathrm{mM}$ $\mathrm{NaCl})$. Crude cell lysates were prepared in modified RIPA buffer containing $50 \mathrm{mM}$ Tris ( $\mathrm{pH} 7.6), 150 \mathrm{mM} \mathrm{NaCl}$, $0.5 \%$ Triton X-100, $0.5 \%$ sodium deoxycholate, $0.1 \%$ SDS, $5 \mathrm{mM} \mathrm{NaF}, 1 \mathrm{mM} \mathrm{Na} \mathrm{VO}_{4}$ and protease inhibitor cocktail (SigmaAldrich, St Louis, U.S.A.). Small aliquots of each lysates were kept for total GluA2 protein levels. The detergent-solubilized lysates were incubated with 50 $\mu \mathrm{l}$ of hydrated Neutravidin-Agarose beads for $4 \mathrm{~h}$ at $4{ }^{\circ} \mathrm{C}$ to isolate biotinylated proteins. After the Neutravidin beads were washed four times with the RIPA buffer, bound proteins were eluted with SDS sample buffer by boiling for $5 \mathrm{~min}$. Isolated biotinylated proteins and whole cell lysates were subsequently analyzed by western blotting with monoclonal anti-GluA2 (1:1,000; 556341, BD Bioscience, Frankin Lakes, NJ, USA). Immunoreactive bands were then probed with HRP-conjugated secondary antibody for $1 \mathrm{~h}$ and developed using the ECL detection system (Thermo Fisher Scientific Inc.). Equal loading of isolated surface proteins was confirmed based on silverstained bands profiles on gels that were pre-run with small aliquots of samples. Optical densities of immunoreactivities were quantified using NIH ImageJ software (downloaded from http://rsb.info.nih.gov/ii/).

\section{Data Analysis}

A sophisticated, free data acquisition and analysis package, the "LTP program" [74], was used to record the data, which had been filtered at $2 \mathrm{kHz}$ and digitized at $10 \mathrm{kHz}$. During whole cell patch recording excitatory postsynaptic current (EPSC) amplitude, series resistance, DC current and input resistance were recorded. To graphically display the data, the amplitude of the EPSCs was normalized against baseline values and plotted against time. In the figures each data point represents the average of two raw data points. In each figure, data are shown as mean \pm SEM. Where appropriate, the statistical significance of the data was established through use of a Student's t test, which was performed on EPSC amplitude measurements obtained during the 5 minutes before and between 25 and 30 minutes following washout of the muscarinic agonist. 


\section{Competing interests}

The authors declare that they have no competing interests.

\section{Authors' contributions}

BAD conducted electrophysiology. JJ participated in the electrophysiology experiments. HS designed and participated in molecular experiments. GHS conducted molecular experiments. DJW participated in electrophysiology. CHD participated production of the M1 agonist. MS, GLC and $\mathrm{KC}$ conceived the original concept of this study and wrote the manuscript. KC supervised the entire project. All authors read and approved the final manuscript.

\section{Acknowledgements}

This work was supported by the BBSRC (KC), UK Alzheimer Research Trust (KC, GLC) and the MRC (KC, GLC). GLC is a Wolfson-Royal Society fellow.

\section{References}

I. Bartus RT, Dean RL 3rd, Beer B, Lippa AS: The cholinergic hypothesis of geriatric memory dysfunction. Science 1982, 217:408-4I4.

2. Whitehouse PJ, Price DL, Struble RG, Clark AW, Coyle JT, Delon MR: Alzheimer's disease and senile dementia: loss of neurons in the basal forebrain. Science 1982, 215:1237-1239.

3. Woolf NJ: A structural basis for memory storage in mammals. Prog Neurobiol 1998, 55:59-77.

4. Gold PE: Acetylcholine modulation of neural systems involved in learning and memory. Neurobiol Learn Mem 2003, 80:194-210.

5. Whitehouse PJ, Price DL, Clark AW, Coyle JT, DeLong MR: Alzheimer disease: evidence for selective loss of cholinergic neurons in the nucleus basalis. Ann Neurol 1981, 10:122-126.

6. Arendt $\mathrm{T}, \mathrm{Big} \mathrm{V}$, Arendt $\mathrm{A}$, Tennstedt $\mathrm{A}$ : Loss of neurons in the nucleus basalis of Meynert in Alzheimer's disease, paralysis agitans and Korsakoff's Disease. Acta Neuropathol (Berl) 1983, 6I: $101-108$.

7. DeKosky ST, Scheff SW: Synapse loss in frontal cortex biopsies in Alzheimer's disease: correlation with cognitive severity. Ann Neurol 1990, 27:457-464.

8. Levey Al: Muscarinic acetylcholine receptor expression in memory circuits: implications for treatment of Alzheimer disease. Proc Natl Acad Sci USA 1996, 93: I354 I- 13546.

9. Forlenza OV, Spink JM, Dayanandan R, Anderton BH, Olesen OF, Lovestone $S$ : Muscarinic agonists reduce tau phosphorylation in non neuronal cells via GSK-3beta inhibition and in neurons. J Neural Transm 2000, 107:1201-1212.

10. Beach TG, Walker DG, Potter PE, Sue LI, Fisher A: Reduction of cerebrospinal fluid amyloid beta after systemic administration of MI muscarinic agonists. Brain Res 200I, 905:220-223.

11. Caccamo A, Oddo S, Billings LM, Green KN, Martinez-Coria H, Fisher $\mathrm{A}$, LaFerla $\mathrm{FM}$ : MI receptors play a central role in modulating AD-like pathology in transgenic mice. Neuron 2006, 49:67I-682.

12. Langmead CJ, Watson J, Reavill C: Muscarinic acetylcholine receptors as CNS drug targets. Pharmacol Therapeutic 2008, I 1 7:232-244.

13. Kirkwood A, Rozas C, Kirkwood J, Perez F, Bear MF: Modulation of long-term synaptic depression in visual cortex by acetylcholine and norepinephrine. J Neurosci 1999, 19:1599-1609.

14. McCoy PA, McMahon LL: Muscarinic receptor dependent longterm depression in rat visual cortex is PKC independent but requires ERK I/2 activation and protein synthesis. J Neurophysiol 2007, 98: 1862-1870.

15. McCoy P, Norton TT, McMahon LL: Layer 2/3 synapses in monocular and binocular regions of tree shrew visual cortex express mAChR-dependent long-term depression and longterm potentiation. J Neurophysiol 2008, 100:336-345.

16. Massey PV, Bhabra G, Cho K, Brown MW, Bashir Zl: Activation of muscarinic receptors induces protein synthesis-dependent long-lasting depression in the perirhinal cortex. Eur J Neurosci 2001, 14:145-152.

17. Jo J, Ball SM, Seok H, Oh SB, Massey PV, Molnar E, Bashir ZI, Cho K: Experience-dependent modification of mechanisms of longterm depression. Nat Neurosci 2006, 9:170-172.

18. Grishin AA, Benquet P, Gerber U: Muscarinic receptor stimulation reduces NMDA responses in CA3 hippocampal pyramidal cells via $\mathrm{Ca}^{2+}$-dependent activation of tyrosine phosphatase. Neuropharmacology 2005, 49:328-337.

19. Scheiderer CL, McCutchen E, Thacker EE, Kolasa K, Ward MK, Parsons D, Harrell LE, Dobrunz LE, McMahon LL: Sympathetic sprouting drives hippocampal cholinergic reinnervation that prevents loss of a muscarinic receptor-dependent long-term depression at CA3-CAI synapses. I Neurosci 2006, 26:3745-3756.

20. Volk LJ, Pfeiffer BE, Gibson JR, Huber KM: Multiple Gq-coupled receptors converge on a common protein synthesis-dependent long-term depression that is affected in fragile $X$ syndrome mental retardation. J Neurosci 2007, 27: I I 624- I I634.

21. Scheiderer CL, Smith CC, McCutchen E, McCoy PA, Thacker EE, Kolasa K, Dobrunz LE, McMahon LL: Coactivation of M(I) muscarinic and alpha $I$ adrenergic receptors stimulates extracellular signal-regulated protein kinase and induces long-term depression at CA3-CAl synapses in rat hippocampus. J Neurosci 2008, 28:5350-5358.

22. Moult PR, Gladding CM, Sanderson TM, Fitzjohn SM, Bashir ZI, Molnar E, Collingridge GL: Tyrosine phosphatases regulate AMPA receptor trafficking during metabotropic glutamate receptor-mediated long-term depression. J Neurosci 2006, 26:2544-2554.

23. Moult PR, Correa SA, Collingridge GL, Fitzjohn SM, Bashir ZI: Coactivation of $\mathrm{p} 38$ mitogen-activated protein kinase and protein tyrosine phosphatase underlies metabotropic glutamate receptor-dependent long-term depression. J Physiol 2008, 586:2499-25I0.

24. Collingridge GL, Olsen RW, Peters J, Spedding M: A nomenclature for ligand-gated ion channels. Neuropharmacology 2009, 56:2-5.

25. Lechleiter J, Hellmiss R, Duerson K, Ennulat D, David N, Clapham D, Peralta E: Distinct sequence elements control the specificity of $\mathbf{G}$ protein activation by muscarinic acetylcholine receptor subtypes. EMBO J 1990, 9:438I-4390.

26. Lechleiter J, Girard S, Clapham D, Peralta E: Subcellular patterns of calcium release determined by $G$ protein-specific residues of muscarinic receptors. Nature 1991, 350:505-508.

27. Berstein G, Blank JL, Smrcka AV, Higashijima T, Sternweis PC, Exton $J H$, Ross EM: Reconstitution of agonist-stimulated phosphatidylinositol 4,5-bisphosphate hydrolysis using purified $\mathrm{ml}$ muscarinic receptor, Gq/I I, and phospholipase C-beta I. J Biol Chem 1992, 267:808I-8088.

28. Felder CC: Muscarinic acetylcholine receptors: signal transduction through multiple effectors. FASEB J 1995, 9:619-625.

29. Artola $A$, Singer $W$ : Long-term depression of excitatory synaptic transmission and its relationship to long-term potentiation. Trends Neurosci 1993, 16:480-487.

30. Mulkey RM, Herron CE, Malenka RC: An essential role for protein phosphatases in hippocampal long-term depression. Science 1993, 261:105I-1055.

31. Mulkey RM, Endo S, Shenolikar S, Malenka RC: Involvement of a calcineurin/inhibitor-I phosphatase cascade in hippocampal long-term depression. Nature 1994, 369:486-488.

32. Watabe AM, Carlisle HJ, O'Dell TJ: Postsynaptic induction and presynaptic expression of group I mGluR-dependent LTD in the hippocampal CAI region. I Neurophysiol. 2002, 87(3): | 395-| 403 .

33. Lefkowitz RJ, Shenoy SK: Transduction of receptor signals by barrestins. Science 2005, 308:512-517.

34. Li P, Kerchner GA, Sala C, Wei F, Huettner JE, Sheng M, Zhuo M: AMPA receptor-PDZ interactions in facilitation of spinal sensory synapses. Nat Neurosci 1999, 2:972-977.

35. Daw MI, Chittajallu R, Bortolotto ZA, Dev KK, Duprat F, Henley JM, Collingridge GL, Isaac JT: PDZ proteins interacting with C-terminal GluR2/3 are involved in a PKC-dependent regulation of AMPA receptors at hippocampal synapses. Neuron 2000, 28:873-886. 
36. Bellone $C$, Luscher C: Cocaine triggered AMPA receptor redistribution is reversed in vivo by $\mathrm{mGluR}$-dependent long-term depression. Nat Neurosci 2006, 9:636-64I.

37. Xia J, Chung HJ, Wihler C, Huganir RL, Linden DJ: Cerebellar longterm depression requires PKC-regulated interactions between GluR2/3 and PDZ domain-containing proteins. Neuron 2000, 28:499-5I0

38. Wyszynski M, Kim E, Dunah AW, Passafaro M, Valtschanoff JG, SerraPages C, Streuli M, Weinberg RJ, Sheng M: Interaction between GRIP and liprin-alpha/SYD2 is required for AMPA receptor targeting. Neuron 2002, 34:39-52.

39. Dunah AW, Hueske E, Wyszynski M, Hoogenraad CC, Jaworski J, Pak DT, Simonetta A, Liu G, Sheng M: LAR receptor protein tyrosine phosphatases in the development and maintenance of excitatory synapses. Nat Neurosci 2005, 8:458-467.

40. Johnson KG, McKinnell IW, Stoker AW, Holt CE: Receptor protein tyrosine phosphatases regulate retinal ganglion cell axon outgrowth in the developing Xenopus visual system. J Neurobiol 200I, 49:99-1I7.

4I. Van Lieshout EM, Van der Heijden I, Hendriks WJ, Van der Zee CE: $A$ decrease in size and number of basal forebrain cholinergic neurons is paralleled by diminished hippocampal cholinergic innervation in mice lacking leukocyte common antigenrelated protein tyrosine phosphatase activity. Neuroscience 200I, I02:833-84I.

42. McCutchen E, Scheiderer CL, Dobrunz LE, McMahon LL: Coexistence of muscarinic long-term depression with electrically induced long-term potentiation and depression at CA3-CAI synapses. J Neurophysiol 2006, 96:3||4-3I2I.

43. Choi SY, Chang J, Jiang B, Seol GH, Min SS, Han JS, Shin HS, Gallagher M, Kirkwood A: Multiple receptors coupled to phospholipase C gate long-term depression in visual cortex. J Neurosci 2005, 25:II 1433-II443.

44. Markram H, Segal M: Acetylcholine potentiates responses to $\mathbf{N}-$ methyl-D-aspartate in the rat hippocampus. Neurosci Lett 1990, II 3:62-65.

45. Harvey J, Balasubramaniam R, Collingridge GL: Carbachol can potentiate $\mathbf{N}$-methyl-D-aspartate responses in the rat hippocampus by a staurosporine and thapsigargin-insensitive mechanism. Neurosci Lett 1993, 162:165-168.

46. Marino MJ, Rouse ST, Levey Al, Potter LT, Conn PJ: Activation of the genetically defined $\mathrm{ml}$ muscarinic receptor potentiates N-methyl-D-aspartate (NMDA) receptor currents in hippocampal pyramidal cells. Proc Natl Acad Sci USA 1998, 95: I | 465-1 I 470.

47. Palmer MJ, Irving AJ, Seabrook GR, Jane DE, Collingridge GL: The group I mGlu receptor agonist DHPG induces a novel form of LTD in the CAI region of the hippocampus. Neuropharmacology 1997, 36:1517-1532.

48. Fitzjohn SM, Kingston AE, Lodge D, Collingridge GL: DHPGinduced LTD in area CAI of juvenile rat hippocampus; characterisation and sensitivity to novel mGlu receptor antagonists. Neuropharmacology 1999, 38:1577-1583.

49. Huber KM, Roder JC, Bear MF: Chemical induction of mGluR5and protein synthesis-dependent long-term depression in hippocampal area CAI. J Neurophysiol 200I, 86:32I-325.

50. Faas GC, Adwanikar H, Gereau RW 4th, Saggau P: Modulation of presynaptic calcium transients by metabotropic glutamate receptor activation: a differential role in acute depression of synaptic transmission and long-term depression. I Neurosci 2002, 22:6885-6890.

5I. Hou L, Klann E: Activation of the phosphoinositide 3-kinaseAkt-mammalian target of rapamycin signaling pathway is required for metabotropic glutamate receptor-dependent long-term depression. J Neurosci 2004, 24:6352-636I.

52. Huang CC, You JL, Wu MY, Hsu KS: Rap I-induced p38 mitogenactivated protein kinase activation facilitates AMPA receptor trafficking via the GDI.Rab5 complex. Potential role in (S)-3,5-dihydroxyphenylglycene-induced long term depression. J Biol Chem 2004, 279: 12286-12292.

53. Scheiderer CL, Dobrunz LE, McMahon LL: Novel form of longterm synaptic depression in rat hippocampus induced by activation of alpha I adrenergic receptors. J Neurophysiol 2004, 91:107I-1077.

54. Jo J, Heon S, Kim MJ, Son GH, Park Y, Henley JM, Weiss JL, Sheng M, Collingridge GL, Cho K: Metabotropic glutamate receptor- mediated LTD involves two interacting $\mathrm{Ca}^{2+}$ sensors, NCS-I and PICKI. Neuron 2008, 60:1095-IIII.

55. Schnabel R, Kilpatrick IC, Collingridge GL: An investigation into signal transduction mechanisms involved in DHPG-induced LTD in the CAI region of the hippocampus. Neuropharmacology 1999, 38: I585-1596.

56. Schnabel R, Kilpatrick IC, Collingridge GL: Protein phosphatase inhibitors facilitate DHPG-induced LTD in the CAI region of the hippocampus. Br J Pharmacol 200I, I 32:1095-II0I.

57. Fitzjohn SM, Palmer MJ, May JER, Neeson A, Morris SAC, Collingridge $\mathrm{GL}:$ A characterisation of long-term depression induced by metabotropic glutamate receptor activation in the rat hippocampus in vitro. J Physiol 200I, 537:42I-430.

58. Collingridge GL, Isaac JT, Wang YT: Receptor trafficking and synaptic plasticity. Nat Rev Neurosci 2004, 5:952-962.

59. Osten P, Khatri L, Perez JL, Kohr G, Giese G, Daly C, Schulz TW, Wensky A, Lee LM, Ziff EB: Mutagenesis reveals a role for ABP/ GRIP binding to GluR2 in synaptic surface accumulation of the AMPA receptor. Neuron 2000, 27:313-325.

60. Perez JL, Khatri L, Chang C, Srivastava S, Osten P, Ziff EB: PICKI Targets Activated Protein Kinase $C\{$ alpha\} to AMPA Receptor Clusters in Spines of Hippocampal Neurons and Reduces Surface Levels of the AMPA-Type Glutamate Receptor Subunit 2. J Neurosci 200I, 21 :54I7-5428.

61. Seidenman KJ, Steinberg JP, Huganir R, Malinow R: Glutamate receptor subunit 2 Serine $\mathbf{8 8 0}$ phosphorylation modulates synaptic transmission and mediates plasticity in CAI pyramidal cells. J Neurosci 2003, 23:9220-9228.

62. Lu W, Ziff EB: PICKI interacts with ABP/GRIP to regulate AMPA receptor trafficking. Neuron 2005, 47:407-42I.

63. Chung HJ, Steinberg JP, Huganir RL, Linden DJ: Requirement of AMPA receptor GluR2 phosphorylation for cerebellar longterm depression. Science 2003, 300:175I-1755.

64. Steinberg JP, Takamiya K, Shen Y, Xia J, Rubio ME, Yu S, Jin W, Thomas GM, Linden DJ, Huganir RL: Targeted in vivo mutations of the AMPA receptor subunit GluR2 and its interacting protein PICKI eliminate cerebellar long-term depression. Neuron 2006, 49:845-860.

65. Mameli M, Balland B, Lujan R, Luscher C: Rapid synthesis and synaptic insertion of GluR2 for $m$ GluR-LTD in the ventral tegmental area. Science 2007, 317:530-533.

66. Dong H, O'Brien RJ, Fung ET, Lanhan AA, Worley PF, Huganir RL: GRIP: a synaptic PDZ domain-containing protein that interacts with AMPA receptors. Nature 1997, 386:279-284.

67. Liu S), Cull-Candy SG: Subunit interaction with PICK and GRIP controls $\mathrm{Ca}^{2+}$ permeability of AMPARs at cerebellar synapses. Nat Neurosci 2005, 8:768-775.

68. DeSouza S, Fu J, States BA, Ziff EB: Differential palmitoylation directs the AMPA receptor-binding protein ABP to spines or to intracellular clusters. J Neurosci 2002, 22:3493-3503.

69. Dong H, Zhang P, Song I, Petralia RS, Liao D, Huganir RL: Characterization of the glutamate receptor-interacting proteins GRIPI and GRIP2. J Neurosci 1999, 19:6930-694I.

70. Ye B, Liao D, Zhang X, Zhang P, Dong H, Huganir RL: GRASP-I: a neuronal RasGEF associated with the AMPA receptor/GRIP complex. Neuron 2000, 26:603-617.

71. Zhang Y, Venkitaramani DV, Gladding CM, Zhang Y, Kurup P, Molnar $\mathrm{E}$, Collingridge GL, Lombroso PJ: The tyrosine phosphatase STEP mediates AMPA receptor endocytosis after metabotropic glutamate receptor stimulation. J Neurosci 2008, 28: $1056 \mid-10566$

72. Ahmadian G, Ju W, Liu L, Wyszynski M, Lee SH, Dunah AW, Taghibiglou C, Wang Y, Lu J, Wong TP: Tyrosine phosphorylation of GluR2 is required for insulin-stimulated AMPA receptor endocytosis and LTD. EMBO J 2004, 23: 1040- 1050.

73. Hayashi T, Huganir RL: Tyrosine phosphorylation and regulation of the AMPA receptor by Src family tyrosine kinases. J Neurosci 2004, 24:6152-6160.

74. Anderson WW, Collingridge GL: The LTP Program: a data acquisition program for on-line analysis of long-term potentiation and other synaptic events. J Neurosci Methods 200I, 108:7|-83. 